\title{
Price-setting Behavior and Competition in Developing Countries: an Analysis of Retail Outlets in Lesotho
}

\author{
Mamello A. Nchake ${ }^{1,2}$ • Lawrence Edwards ${ }^{2}$ • \\ Asha Sundaram ${ }^{2}$
}

Received: 3 October 2017 / Revised: 19 February 2018

Accepted: 6 March 2018 /Published online: 21 March 2018

(C) The Author(s) 2018

\begin{abstract}
We study the relationship between price-setting behavior and the degree of competition in a setting where markets and information flows are relatively imperfect. Using a unique dataset that combines survey data on retail outlets in Lesotho, and detailed historical information on their product prices, we find a non-monotonic relationship between the frequency of price changes and perceived competition, measured by the number of reported competitors. This non-monotonic relationship is consistent with a model of increasing costs of coordinating price changes under tacit collusion with few competitors, and a breakdown of collusion at higher levels of competition. By exploring the nature of the relationship between competition and price rigidity, our study has implications for macroeconomic and competition policy, and underscores the scope for interaction between the two.
\end{abstract}

Keywords Price rigidity $\cdot$ Competition $\cdot$ Survey data $\cdot$ Micro price data $\cdot$ Emerging economies

JEL Classification $\mathrm{E} 30 \cdot \mathrm{D} 40 \cdot \mathrm{D} 22 \cdot \mathrm{L} 21$

Electronic supplementary material The online version of this article (https://doi.org/10.1007/s10842-0180275-6) contains supplementary material, which is available to authorized users.

Mamello A. Nchake

mnchake@yahoo.com

Lawrence Edwards

Lawrence.Edwards@uct.ac.za

Asha Sundaram

assundar.wk@gmail.com

1 Department of Economics, National University of Lesotho, Maseru, Lesotho

2 School of Economics, University of Cape Town, Rondebosch, Cape Town 7701, South Africa 


\section{Introduction}

Evidence of price rigidities is widespread. Prices are found to be sticky and price increases and decreases often respond asymmetrically to cost and demand shocks (Blinder et al. 1998; Peltzman 2000). Accounting for these rigidities has key implications for economic theory (Carlton 1986; Blinder 1991; Blinder et al. 1998; Peltzman 2000), macro models (Klenow and Malin 2011) and the conduct of monetary and other economic policies (Clarida et al. 1999; Schmitt-Grohe and Uribe 2004; Greenslade and Parker 2012).

The literature posits that a firm's price-setting behavior is influenced by the degree of competition it faces (Rotemberg and Saloner 1987). In competitive markets, a firm's pricing decision is expected to respond more closely to cost and demand shocks than in markets characterized by imperfect competition, where price adjustments may be delayed to avoid breaking tacit pricing agreements (Álvarez and Hernando 2007b). Notwithstanding this theoretical prediction, the empirical literature that explores the link between price-setting behavior and the degree of competition is both diverse and contentious. While some empirical studies using high frequency product-level price data find supporting evidence for the positive association between competition and the frequency of price changes (Carlton 1986; Hall et al. 2000; Álvarez and Hernando 2007b), other studies find the opposite effect (Domberger 1979), or no effect at all (Weiss 1993; Bils and Klenow 2004).

One explanation for this empirical inconsistency might be that these studies assume a monotonic relationship between competition and the frequency of price changes, whereas the relationship may be non-monotonic, as is theoretically argued by Hanazono and Yang (2007). Alternatively, the inconsistency may reflect the fact that these available studies draw on different data bases that are not necessarily comparable. Some studies, such as Álvarez et al. (2005) for Spain, draw on detailed producer price data, while others use information on pricesetting behavior obtained from firm surveys (see Aucremanne and Druant (2005) for Belgium, Hall et al. (2000) for the UK, Apel et al. (2005) and Álvarez and Hernando (2007b) for the Euro Area). While the price-based studies are able to exploit detailed historical information on price changes, they lack information on firm characteristics, including perceived competition. On the other hand, studies that employ survey data can draw on rich information on firm characteristics, but may lack detailed and historical information on observed changes in prices.

In this study, we address both these limitations. We investigate potential non-monotonicity in the relationship between price rigidity and perceived competition explicitly. Particularly, we study the relationship between the frequency of price changes and perceived competition in retail outlets in Lesotho, a small economy in Southern Africa. Lesotho provides a relevant case study for our purpose, since its markets remain relatively open, and government intervention in price-setting is relatively low. ${ }^{1}$ However, like many developing countries, access to transport and communications infrastructure is poor and few firms have access to computers, the internet and email.

We posit that in an environment of asymmetric information, the co-ordination costs involved with price changes when firms tacitly collude rise as the number of competitors initially increases, implying a negative association between the frequency of price changes and competition. However, as the number of firms rises, collusion is harder to sustain and finally breaks down, after which more competition is associated with more frequent price changes.

\footnotetext{
${ }^{1}$ For instance, our survey data on retail outlets show that only $3.38 \%$ of outlets reported that their pricing strategies were determined by the government.
} 
We utilise a unique dataset that combines survey data on retail firms (outlets) with detailed, historical information on prices of their products. The micro price database consists of monthly consumer prices for products over the period January 2011 through December 2012. The outlet survey data consist of 250 retail outlets drawn from face-to-face questionnaires administered to managers/owners of these outlets across Lesotho in 2013. ${ }^{2}$ The survey questionnaire contains detailed information on outlet attributes, price-setting behavior, number of competitors and costs. Our integrated database combines the comprehensive nature of the micro price data in terms of product range and coverage over time, with detailed information on outlet characteristics and manager responses to how prices are set, reviewed and changed. In particular, while most studies assume that all firms in a particular market compete, we use information on the number of competitors that managers perceive when they set their prices. Our integrated database hence allows for a richer analysis of price-setting behaviour than is possible in other studies that use either micro price or firm-level survey data.

Controlling for product-level, time-invariant demand and cost shocks, we find evidence of a non-monotonic relationship between the frequency of price changes and the perceived number of competitors. At low levels of competition, a rise in the number of competing outlets reduces the frequency of price changes within outlets, but the relationship switches to positive as the of number competitors increase. Additionally, we find that evidence of non-monotonicity is stronger for homogeneous, relative to differentiated products, consistent with our conceptual framework. We also find that evidence of non-monotonicity is more pronounced for price decreases than for price increases. Finally, our results are robust to alternate estimation technique that accounts for the bounded and fractional nature of our dependent variable.

To our knowledge, our study is the first to document empirical evidence for a non-monotonic relationship between price rigidity and competition in the non-financial sector. ${ }^{3}$ We show that in imperfectly competitive markets, an increase in the number of retail firms might lead to greater price rigidity. We hence underscore the need to coordinate macroeconomic policy and competition policy. Finally, there is strikingly little on the relationship between price rigidity and competition in developing countries, where markets are more rigid and where 'thin' markets create frictions to price adjustments different from advanced economies (Nchake et al. 2015).

The rest of the paper is structured as follows. Section 2 outlines our conceptual framework. Sections 3 describes the data. Section 4 analyzes the relationship between the frequency of price changes and competition in a regression framework and Section 5 concludes.

\section{Conceptual Framework}

We adapt the conceptual framework proposed in Hanazono and Yang (2007). ${ }^{4}$ They consider an infinitely repeated Bertrand game with two identical firms, where firms experience a demand shock in each period, and receive private information (a signal) on the nature of the

\footnotetext{
${ }^{2}$ The survey sample is large relative to other studies, particularly when taking into account the relative sizes of the economies. For example, Blinder (1991) and Blinder et al. (1998) cover approximately 200 firms in the US, the survey of UK firms used by Greenslade and Parker (2012) covers 693 firms. These studies cover mostly producers, while the focus in this study is on retailers.

${ }^{3}$ Jackson III (1997) and Lago-Gonzalez and Salas-Fumas (2005) provide evidence of a non-monotonic relationship between price rigidity of loan and consumer deposit interest rates and competition.

${ }^{4}$ We note that our goal here is to provide a framework for interpreting our results, rather than to explicitly model and estimate price rigidity and competition.
} 
shock. ${ }^{5}$ Due to asymmetric information, one firm cannot observe the other's signal. At the end of the period, firms observe demand. Firms can either choose a sorting pricing scheme, where they charge different prices for different signals, or a pooling scheme, where they charge the same price regardless of the demand signal (price rigidity).

Under the sorting scheme, firms enjoy information gains because they exploit the information in the signal, though these gains are mitigated if the signal is noisy. However, for this scheme to be maintained in equilibrium, firms must have no incentive to charge a price assigned to a different signal. Given that the signal is private, deviations cannot be detected, and price distortions or future punishments are necessary to maintain this scheme. These impose coordination costs. On the other hand, the pooling scheme involves no coordination costs. In an environment where signals are noisy, as is likely to be the case in most developing countries (and sometimes in advanced countries), where information flows are less than perfect, the authors show that firms may find a pooling scheme optimal, because the information gains associated with a sorting scheme are not sufficient to outweigh the associated coordination costs.

We argue that this framework is well-suited to Lesotho, where information flows are potentially imperfect and coordination is costly. We find that very few outlets in our sample own communication devices like telephones and computers or have access to internet tools. From survey responses, we find that only $37 \%$ of outlets own a computer, while only $45 \%$ of them own a telephone. In the World Bank's Enterprise Survey on Lesotho conducted in the year 2008 , about $42 \%$ of firms had a telephone, only $23 \%$ had a website and about $57 \%$ used email. This hints at significant barriers to information flows, such that coordination costs under tacit collusion among outlets in our study are likely to be high.

As the number of firms in a market increases, coordination costs increase. This is because, with a larger number of firms, the probability that one firm charges a price assigned to a different signal increases, increasing the punishments or price distortions necessary to sustain a sorting equilibrium. Hence, initially, a pooling scheme is more likely to be optimal with more competitors, implying a negative association between the frequency of price changes and the number of competitors. ${ }^{6}$ As the number of firms increases, collusion cannot be sustained, and it breaks down. After this point, the likelihood that firms change prices in response to shocks increases with the number of competitors because the opportunity cost of not adjusting to the optimal price is larger the more competitive the market (Álvarez and Hernando 2007a).

Formally, the frequency of price changes as a function of the number of competitors can be specified as:

$$
\begin{aligned}
& f\left(n_{i}\right)=b(s)-c\left(n_{i}\right) \quad \text { if } n_{i} \leq n_{c} \\
& =b(s) F\left(n_{i}\right) \quad \text { if } n_{i}>n_{c}
\end{aligned}
$$

Here, $s$ captures the extent of demand fluctuations in the market, $n_{i}$ is the number of competitors for firm $i, n_{c}$ is the number of firms after which collusion is unsustainable. $b(s)$ captures the relationship between demand fluctuations and the frequency of price changes. $c\left(n_{i}\right)$ captures the costs of coordinating price changes as a function of the number of competitors. $F\left(n_{i}\right)$ captures the relationship between competition and the frequency of price changes when there is no collusion. We assume that $F^{\prime}>0, b^{\prime}>0$ and $c^{\prime}>0$. Note that in a

\footnotetext{
${ }^{5}$ Although in the paper we base our conceptual framework on demand shocks, the intuition could also apply to supply shocks.

${ }^{6}$ Note that the frequency of price changes in a monopoly (relative to a duopoly) would be higher in this framework, since there are no coordination costs in a monopoly.
} 
monopoly, $f\left(n_{i}\right)=b(s)$, that is, the frequency of price changes depends on the extent of demand fluctuations in the market. ${ }^{7}$ Hence,

$$
\begin{aligned}
f^{\prime}\left(n_{i}\right) & =-c^{\prime}\left(n_{i}\right)<0 \quad \text { if } n_{i} \leq n_{c} \\
& =F^{\prime}\left(n_{i}\right)>0 \quad \text { if } n_{i}>n_{c}
\end{aligned}
$$

This yields a non-monotonic relationship between $n_{i}$ and $f$. Drawing from these theoretical underpinnings, we empirically analyze this relationship using our data on the perceived number of competitors reported by retail outlets and the frequency with which these outlets change product prices. We estimate:

$$
f_{i p}=\beta_{0}+X\left(\beta_{1} n_{i}\right)+\beta_{2} Y_{i}+\beta_{3} I_{p}+\varepsilon_{i p}
$$

Here, $f_{i p}$ is the frequency of price changes in outlet $i$ for product $p$ and $n_{i}$ is the number of competitors reported by the outlet. We first estimate $X\left(\beta_{1} n_{i}\right)$ as a linear function, and subsequently explore non-monotonicity by introducing a linear and a squared term of the number of reported competitors. $Y_{i}$ and $I_{p}$ are outlet and product specific characteristics respectively, while $\varepsilon_{i p}$ is an idiosyncratic error term. ${ }^{8}$

\section{Data}

\subsection{Outlet Price-Setting Survey}

The price-setting survey was designed to collect detailed information on outlet characteristics, with a particular focus on how prices were set and changed. The motivation behind the study was to gather information on price setting behaviour in a developing country context, given that firm level information on such behaviour is scarce for these countries. The questionnaire was designed, using the World Bank Enterprise Survey questionnaires and those of Blinder (1991) and Fabiani et al. (2006), in consultation with researchers within SALDRU, University of Cape Town. ${ }^{9}$ The survey was administered to outlets that the Lesotho Bureau of Statistics (BOS) uses for the collection of monthly Consumer Price Index data during the first 2 weeks of March and April 2013. ${ }^{10}$ From the 420 retail and services outlets that were surveyed, we exclude all outlets that provide services, since we focus on goods retailers. Outlets whose

\footnotetext{
${ }_{7}$ Note that $b(s) F\left(n_{i}\right) \rightarrow b(s)$ as $n_{i} \rightarrow \infty$. In other words, as the market structure approaches perfect competition, we would expect the frequency of price changes to be unrelated to the number of competitors. This hints at a second non-linearity as the relationship between the number of competitors and the frequency of price changes switches from positive to zero at a very large number of perceived competitors. We argue that this is not relevant for our empirical analysis because most firms in our sample operate under imperfect competition and the largest number of perceived competitors in our sample is 25 .

${ }^{8}$ We do not explore higher order relationships due to concerns of power in the data.

${ }^{9}$ The survey questionnaire and additional details on the implementation of the survey are available from the authors upon request. For additional information on the survey, also refer to the PEDL report at http://pedl.cepr. org/content/consumer-price-rigidities-lesotho-role-outlet-characteristics-and-competition

${ }^{10}$ The BOS collects prices from 774 outlets, but we did not survey those outlets where prices are only collected once or twice a year (taxi fares, housing rents, petrol and diesel prices) and where prices were subject to regulatory controls (water and electricity companies, hospitals and schools, except for driving schools). The response rate on the outlets we surveyed was $81.5 \%$ which is relatively high compared to other surveys in the literature (for example, Blinder 1991 reported 50\% for the US; Apel et al. 2005, 49\% for Sweden and; Greenslade and Parker 2012 reported 30\% for the UK).
} 
price-setting strategies are not determined within the outlet, but by the head office, parent company, business council or government are also excluded, since the frequency of price changes in these outlets is likely not endogenous to the individual outlet.

\subsection{Micro Price Data}

We also utilize historical product price data for these outlets from January 2011 through December 2012, provided by the Bureau of Statistics, Lesotho. Each individual price record (termed price quote) for a product has information on the date (month and year) of the transaction, the retail outlet's name, district, product description (including brand in many cases) and its unit code, and the price at which it is sold by the outlet. Since we are provided with outlet names, we are able to merge the micro price data with the corresponding outlet's survey responses. We are hence able to trace the pricing history of individual products within each retail outlet over the period 2011-2012. ${ }^{11}$ Nchake et al. (2015) provide further details on the price data.

Since many of the retailers sell multiple products, we only consider products in an outlet's main product group. Note that our survey questions on competition also pertain to the outlet's main product group. ${ }^{12}$ On average, in our survey, the main product group of an outlet constitutes $79.5 \%$ of the total value of sales of each outlet in our data. Therefore, we argue that the price-setting rule applied to the main product group is broadly representative of the outlet's pricing behaviour in general. After excluding outlets for which we have no information on the frequency of price changes for the main product group and outlets that have missing information on key control variables, our final sample in the merged dataset consists of 134 products sold in 210 retail outlets. ${ }^{13} 52 \%$ of the outlets are chain stores and like in most developing economies with low levels of urbanization, a majority (55\%) of outlets are located in rural areas. ${ }^{14}$ From Table 1, the average size (employment) is around eight and the average number of perceived competitors in our sample is around three outlets.

\subsection{Stylised Facts on Price Setting Behaviour in Lesotho}

There are a number of stylised facts on price setting behaviour emanating from retail outlets level data in Lesotho. Table 2 presents descriptive statistics on various measures commonly used in the literature of the degree of competition faced by retail outlets in our sample. These inferred competition measures include the following (each captured by a question in the survey questionnaire): (i) the number of outlets that use mark-up pricing; (ii) whether an outlet reduced prices in response to the lowering of a competitor's price; (iii) whether an outlet regarded reductions in a close competitor's price as important or very important in influencing it to lower its price; and (iv) whether an outlet rated the fear of a rise in its competitor's price as an important factor stopping it from raising its own price.

From Table 2, almost 95\% of outlets report using mark-up pricing. Following Alvarez et al. (2006), Álvarez and Hernando (2007a) and Greenslade and Parker (2012) who use mark-up pricing

\footnotetext{
${ }^{11}$ A limitation of the data is that it is not possible to identify price changes in response to temporary promotions and seasonal sales.

${ }_{12}^{12}$ For the full list of product groups, see Table 4 in the supplementary material.

${ }^{13}$ For the full list of products, see Table A1 in the supplementary material. For a list of outlets in the sample by district and a map of Lesotho, see Table A2 and Figure A1 in the supplementary material.

${ }^{14}$ A chain is a group of retail or services outlets dealing in the same products. These outlets share a brand and central management and usually have a standardized business method and practice.
} 
Table 1 Summary statistics by frequency of price changes and size of firm

\begin{tabular}{lllllll}
\hline & $\begin{array}{l}\text { Simple } \\
\text { average }\end{array}$ & Median & Min & Max & $\begin{array}{l}\text { Standard } \\
\text { deviation }\end{array}$ & No. of outlets \\
\hline Number of competitors & 3.43 & 3 & 0 & 25 & 3.25 & 210 \\
Outlet size (total employment) & 8.10 & 5 & 1 & 75 & 9.91 & 210 \\
\hline
\end{tabular}

Source: Outlet survey data, authors' calculations

The sample comprises of 210 retail outlets

as an indicator of imperfectly competitive markets, these results suggest a high degree of market power in the Lesotho retail market compared to other economies. For example, the share of firms using mark-up pricing relative to competitor pricing is substantially higher in Lesotho compared to countries in the Euro area (Alvarez et al. 2006; Álvarez and Hernando 2007a) and the United Kingdom (Greenslade and Parker 2012). This also holds when comparing Lesotho to other emerging economies such as Turkey (Şahinőz and Saraçoğlu 2008) and Romania (Copaciu et al. 2010). This evidence for imperfect competition is bolstered by survey responses to all three subsequent questions in Table 2, where fewer outlets report being concerned about competitors while setting prices. This is consistent with the idea that in a developing country like Lesotho, outlets face an imperfectly competitive environment, at least in their local market.

One concern is that we do not capture the nature of competition among retail outlets comprehensively without accounting for the informal sector which accounts for a large proportion of economic activity in several developing economies. However, in our survey, $69 \%$ of outlets say that competition from the informal sector is not or only a minor obstacle for them. We confirm this with data on retail and services outlets from the World Bank's Enterprise Survey for Lesotho conducted in the year 2008. In the World Bank's survey, 66\% firms say that competition from the informal sector is no or only a minor obstacle. Hence, we argue that competition from the informal sector is not a major concern for retail outlets in Lesotho.

Table 3 presents a breakdown of price records by major product group. The data in the table cover a sample of 7015 monthly price quotes. Over $80 \%$ of price quotes are made up of food

Table 2 Descriptive statistics by degree of competition to the outlet, share total responses

\begin{tabular}{lcc}
\hline & Observations number & Observation share (\%) \\
\hline Share of outlets that use mark-up pricing & \\
Retail outlets & 198 & 94.7 \\
Did you reduce price in response to reduction in price by competitor? & \\
No & 137 & 73.3 \\
Yes & 50 & 26.7 \\
How important is reduction in close competitor's price in terms of influencing you to lower price? \\
Unimportant & 95 & 46.6 \\
Minor importance & 25 & 12.3 \\
Important & 39 & 19.1 \\
Very important & 45 & 22.1 \\
What stops you from increasing price & - fear competitor's price will remain fixed? \\
Unimportant & 84 & 40.2 \\
Minor importance & 24 & 11.5 \\
Important & 38 & 18.2 \\
Very important & 63 & 30.1 \\
\hline
\end{tabular}

Source: Outlet survey data, authors' calculations

The sample comprises of 210 retail outlets 
products, followed by household furniture and equipment at $5.2 \%$, clothing and footwear at $5.8 \%$ and alcoholic beverages at $2.2 \%$. Other product groups each make up less than $1 \%$. Table 4 provides descriptive statistics for the frequency of monthly price changes by product group from the micro price data. The frequency of price changes is measured for each product group sold by an outlet as the number of times an outlet changes its price over the period 2011-2012. ${ }^{15}$ We see wide variation in the frequency of price changes by product group. Food and tobacco show a high frequency of price changes while household furniture and equipment and beverages show the lowest.

We draw from Nchake et al. (2015) to provide further background context on price setting behaviour in Lesotho. Using micro price data for the period March 2002 and December 2009, the study finds substantial heterogeneity in the frequency of price changes across retail outlets, products and time. Almost a third of all the 229 product items included in the study change price every month, suggesting that individual prices change on average every 3.2 months. Price changes in Lesotho are driven by a combination of idiosyncratic productivity or cost shocks. The findings also reveal a wide range of menu costs across products and time, as average price changes are found to be large in absolute terms with many small price changes. Variations in the frequency of price changes are important in driving inflation dynamics in Lesotho as rising inflation was more closely linked to higher frequency of price increases and lower frequency of price decreases than variations in the average size of price changes.

\section{Price-Rigidity and Competition}

\subsection{Regression Analysis of the Relationship Between the Frequency of Price Changes and Competition}

Various measures of the degree of competition in the product market are used in related empirical literature. Hoeberichts and Stokman (2006) and Vladova (2012), for example, use responses on the degree of perceived competition by Netherlands and Bulgarian firms, respectively; Bayoumi et al. (2004) use product mark-ups in Europe; and Álvarez and Hernando (2007b) use the importance that firms in the Euro Area attached to changes in competitors' prices in explaining its own price reductions.

For our regression analysis, we employ the number of competitors reported by the retail outlet in our survey as the measure of perceived competition. We argue that this is the preferred measure of competition available to us from our survey, since it is more refined and less subjective than a simple binary outcome (or a categorical outcome) of how important a competitor's price response is in the pricing decision. ${ }^{16}$ In addition, using the number of competitors as reported by the outlet allows us to tease out a potentially non-monotonic relationship. ${ }^{17}$

\footnotetext{
${ }^{15}$ We calculate this as the number of months between January 2011 and December 2012 in which the outlet changed its price divided by the total number of months.

${ }^{16}$ There are a number of measures for market concentration and perceived competition, but our data does not contain information on any measurements of market concentration such as market share.

${ }^{17}$ One limitation of using this measure is that different retail firms may use different measures to define relevant markets or to identify their potential competitors. However, in the survey, we ask retail firms about main competitors of their main product.
} 
Table 3 Price records by major group, January 2011 through December 2012

\begin{tabular}{|c|c|c|c|c|}
\hline & \multicolumn{2}{|c|}{ Price quotes } & \multicolumn{2}{|c|}{ Product items } \\
\hline & Number & Percent & Number & Percent \\
\hline Food & 5990 & 85.4 & 69 & 51.5 \\
\hline Non-alcoholic beverages & 15 & 0.2 & 8 & 6.0 \\
\hline Alcoholic beverages & 156 & 2.2 & 3 & 2.2 \\
\hline Tobacco and narcotics & 2 & 0.0 & 1 & 0.8 \\
\hline Clothing and footwear & 404 & 5.8 & 11 & 8.2 \\
\hline Fuel & 18 & 0.3 & 5 & 3.7 \\
\hline Household furniture and equipment & 363 & 5.2 & 25 & 18.7 \\
\hline Household operations & 17 & 0.2 & 4 & 3.0 \\
\hline Transport equipment & 36 & 0.5 & 2 & 1.5 \\
\hline Personal care & 13 & 0.2 & 6 & 4.5 \\
\hline Total & 7014 & 100 & 134 & 100 \\
\hline
\end{tabular}

Source: BOS historical price data, Lesotho

1) The sample comprises of 134 products. 2) Price data are from January 2011 through December 2012. 3) Product groups are based on a modification of the Classification of Individual Consumption by Purpose (COICOP, United Nations, http://unstats.un.org/unsd/cr/registry/regcst.asp?Cl=5)

To reiterate before the analysis, a further advantage of our database is that it combines detailed product-level price data for each outlet with in-depth information on various characteristics of that outlet. In analyzing the frequency of price changes, we are therefore able to control for product heterogeneity far more precisely than in other survey-based studies, in addition to controlling for outlet characteristics.

We first posit a linear relationship between competition and price-rigidity that is commonly estimated in the literature (Álvarez and Hernando 2007b). We measure price-rigidity for each product sold by an outlet as the number of non-zero monthly price changes divided by the number of all monthly price observations for a specific outlet and product over the period 2011-2012 (henceforth, the frequency of price changes). ${ }^{18}$

Drawing from Eq. (3), we regress the frequency of price changes on the reported number of competitors (Number of competitors). Further, we include dummy variables that equal one if the outlet is located in an urban area (Urban), in a mall (Mall location) and if it is part of a chain (Chain). We also include dummies for outlet size (measured by total employment), and ownership of storage facilities (Storage) as this might determine the outlet's ability to hold inventory. ${ }^{19}$

To control for cost and demand shocks at the outlet level, we follow Álvarez and Hernando (2007b) and include dummy variables that equal one if outlets assessed as important or very important the role of labour costs (Labour costs) and demand (Demand) in driving price changes. To control for material input costs (cost of sourcing the good from the producer or wholesalers), we include (Material input costs) a dummy variable that is equal to one if outlets assessed these costs as important or very important. The degree of cost shocks may differ across industries. To account for these differences, we include product group fixed effects that control for product group-specific time-invariant shocks to demand or supply related factors,

\footnotetext{
${ }^{18}$ Freq $_{i k}=\left(\frac{1}{T_{i k}-1}\right) \sum_{i k} I_{i k t}$, for product $k$ sold in retail outlet $i$. Tik is the number of monthly observations of the price of product $k$ sotif in outlet $i$, pikt. Iik, $t$ is an indicator variable equal to 1 if pikt $\neq$ pikt-1 and 0 if pikt $=p i k t-1$.

19 The storage can either be rented or owned.
} 
Table 4 Descriptive statistics of frequency of price change by product groups

\begin{tabular}{llcll}
\hline & Simple average & Median & $\begin{array}{l}\text { Implied mean } \\
\text { duration (months) }\end{array}$ & $\begin{array}{l}\text { Implied median } \\
\text { duration (months) }\end{array}$ \\
\hline Food & 27.9 & 22.7 & 3.6 & 4.4 \\
Non-alcoholic beverages & 14.3 & 14.3 & 7.0 & 7.0 \\
Alcoholic beverages & 13.1 & 11.8 & 7.6 & 8.5 \\
Tobacco and narcotics & 28.3 & 28.3 & 3.5 & 3.5 \\
Clothing and footwear & 13.5 & 7.1 & 7.4 & 14.0 \\
Fuel & 20.5 & 8.7 & 4.9 & 11.5 \\
Household furniture and equipment & 10.8 & 8.7 & 9.3 & 11.5 \\
Household operations (goods) & 16.9 & 13.0 & 5.9 & 7.7 \\
Transport equipment & 19.9 & 17.8 & 5.0 & 5.6 \\
Personal care (goods) & 15.4 & 0.0 & 6.5 & 0.0 \\
Total & 25.6 & 21.7 & 3.9 & 4.6 \\
\hline
\end{tabular}

1) The sample comprises of 134 products. 2) Price data are from January 2011 through December 2012. 3) Product groups are based on a modification of the Classification of Individual Consumption by Purpose (COICOP, United Nations, http://unstats.un.org/unsd/cr/registry/regcst.asp?Cl=5

like raw-material prices. Finally, we include district fixed effects to control for region-specific shocks and cluster standard errors at the retail outlet level.

The dependent variable (Frequency of price changes) is at the outlet-product-level, averaged over the period January 2011 through December 2012. Our key independent variable of interest (Number of competitors) varies by outlet, and is obtained from our survey data collected in 2013.

\subsection{Results}

Results are presented in Table 5. In the first column, we estimate the baseline regression without controls or fixed effects. In the second column, we control for outlet-specific characteristics. Large and medium retail outlets are found to change prices more often and, as expected, retail outlets with storage facilities have a lower frequency of price changes. In column 3, we include a set of district and product fixed effects to control for time-invariant, unobserved heterogeneity at the district-and product-level. Finally, in column 4, we measure competition by an indicator variable (Dcompetition) that equals one if the firm perceives at least one competitor and zero otherwise. Across all columns, we find no systematic relationship between the frequency of price changes and perceived competition by retail outlets.

Next, in Table 6, we explore a potentially non-monotonic relationship between the frequency of price changes and competition by including a squared term of the number of competitors reported by the outlet. Like in Table 5, in column 1, we look at pure correlations. We introduce control variables in column 2 and product and district fixed effects in column 3 and input costs in column 4. In column 5, we include control variables for size and size squared to account for the fact that non-linearity in competition effects may actually be picking up non-linearity in outlet size.

In column 2, we now find a significant non-monotonic relationship between the frequency of price changes and the number of competitors reported by the outlet that is robust to the inclusion of outlet characteristics. While the coefficient on competition is statistically significant but negative, the coefficient on the squared term is positive and significant. 
Table 5 Linear regression of the frequency of price changes on perceived competition

\begin{tabular}{|c|c|c|c|c|}
\hline Variables & (1) & (2) & (3) & (4) \\
\hline Competition & $\begin{array}{l}-0.0032 \\
(0.002)\end{array}$ & $\begin{array}{l}-0.0037 \\
(0.003)\end{array}$ & $\begin{array}{l}-0.0006 \\
(0.002)\end{array}$ & \\
\hline Dcompetition & & & & $\begin{array}{l}-0.0065 \\
(0.013)\end{array}$ \\
\hline Firm size: Medium & & $\begin{array}{l}0.0245^{*} \\
(0.013)\end{array}$ & $\begin{array}{l}0.0015 \\
(0.010)\end{array}$ & $\begin{array}{l}0.0018 \\
(0.010)\end{array}$ \\
\hline Firm size: Large & & $\begin{array}{l}0.0569 * * \\
(0.023)\end{array}$ & $\begin{array}{l}0.0160 \\
(0.017)\end{array}$ & $\begin{array}{l}0.0147 \\
(0.017)\end{array}$ \\
\hline Labour costs & & $\begin{array}{l}-0.0156 \\
(0.012)\end{array}$ & $\begin{array}{l}-0.0074 \\
(0.010)\end{array}$ & $\begin{array}{l}-0.0082 \\
(0.010)\end{array}$ \\
\hline Demand & & $\begin{array}{l}-0.0056 \\
(0.012)\end{array}$ & $\begin{array}{l}-0.0196 * * \\
(0.010)\end{array}$ & $\begin{array}{l}-0.0194 * * \\
(0.010)\end{array}$ \\
\hline Material input costs & & $\begin{array}{l}-0.0154 \\
(0.022)\end{array}$ & $\begin{array}{l}-0.0002 \\
(0.021)\end{array}$ & $\begin{array}{l}-0.0045 \\
(0.010)\end{array}$ \\
\hline Chain & & $\begin{array}{l}0.0038 \\
(0.012)\end{array}$ & $\begin{array}{l}0.0148 \\
(0.009)\end{array}$ & $\begin{array}{l}0.0150 \\
(0.009)\end{array}$ \\
\hline Storage & & $\begin{array}{l}-0.0303 * * \\
(0.015)\end{array}$ & $\begin{array}{l}-0.0295^{* * *} \\
(0.013)\end{array}$ & $\begin{array}{l}-0.0302^{* * *} \\
(0.013)\end{array}$ \\
\hline Mall location & & $\begin{array}{l}0.0126 \\
(0.017)\end{array}$ & $\begin{array}{l}0.0039 \\
(0.014)\end{array}$ & $\begin{array}{l}0.0032 \\
(0.013)\end{array}$ \\
\hline Urban & & $\begin{array}{l}-0.0252 * \\
(0.013)\end{array}$ & $\begin{array}{l}0.0022 \\
(0.010)\end{array}$ & $\begin{array}{l}0.0017 \\
(0.010)\end{array}$ \\
\hline Constant & $\begin{array}{l}0.2658 * * * \\
(0.009)\end{array}$ & $\begin{array}{l}0.3031 * * * \\
(0.026)\end{array}$ & $\begin{array}{l}0.3246 * * * \\
(0.023)\end{array}$ & $\begin{array}{l}0.3320 \text { *** } \\
(0.020)\end{array}$ \\
\hline Observations & 7012 & 7012 & 7012 & 7012 \\
\hline Adjusted R-squared & 0.00 & 0.01 & 0.07 & 0.07 \\
\hline Clusters & 210 & 210 & 210 & 210 \\
\hline Fixed effects & & & & \\
\hline Product & $\mathrm{N}$ & $\mathrm{N}$ & $\mathrm{Y}$ & $\mathrm{Y}$ \\
\hline District & $\mathrm{N}$ & $\mathrm{N}$ & $\mathrm{Y}$ & $\mathrm{Y}$ \\
\hline
\end{tabular}

1) Regressions use the integrated survey and BOS historical price data. 2) The monthly average frequency of price changes are for the period January 2011 to December 2012 and independent variables are from the survey conducted in 2013. 3) Small outlets (5 employees or less) are the omitted category in the outlet size variable. Medium outlets employ 6 to 20 employees, while large outlets employ above 20. 4) Robust standard errors clustered at the outlet level in parentheses. 5) *** $p<0.01, * * p<0.05, * p<0.1$

This suggests that at low levels of competition, a rise in the number of competing outlets reduces the frequency of price changes within outlets, but that when the number of competitors is large, more competitors are associated with an increase in the frequency of price changes. The result of a non-monotonic relationship between competition and the frequency of price changes holds when we include product group and district fixed effects (column 3 ) and control for non-monotonicity in the effect of size on the frequency (columns 4 and 5).

The non-monotonic relationship is clearly shown in Fig. 1 that plots, using the estimates from column 4, the predicted relationship between competition and frequency for the base outlet (small rural outlet selling food products in Maseru, with no storage facilities, not located in mall and that does not find demand or labour shocks very important factors driving price changes). The diagram shows that the frequency of price changes for outlets with one competitor, for example, is $38 \%$ and it declines to $36 \%$ as the number of competitors increases to 5 , but increases to $39 \%$ as the number of competitors increases to 15 and then to $44 \%$ at 20 competitors. 
Table 6 Linear regression of the frequency of price changes on perceived competition - Exploring the nonmonotonicity

\begin{tabular}{|c|c|c|c|c|c|}
\hline Variables & (1) & (2) & (3) & (4) & $(5)$ \\
\hline Number of competitors & $\begin{array}{l}-0.0090 * * \\
(0.004)\end{array}$ & $\begin{array}{l}-0.0131 * * * \\
(0.004)\end{array}$ & $\begin{array}{l}-0.0071 * * \\
(0.003)\end{array}$ & $\begin{array}{l}-0.0083 * * * \\
(0.003)\end{array}$ & $\begin{array}{l}-0.0078 * * * \\
(0.003)\end{array}$ \\
\hline Sqr of number of competitors & $\begin{array}{l}0.0004 \\
(0.000)\end{array}$ & $\begin{array}{l}0.0006^{* * *} \\
(0.000)\end{array}$ & $\begin{array}{l}0.0004 * * * \\
(0.000)\end{array}$ & $\begin{array}{l}0.0005^{* * * *} \\
(0.000)\end{array}$ & $\begin{array}{l}0.0005 * * * \\
(0.000)\end{array}$ \\
\hline Firm size: Medium & & $\begin{array}{l}0.0282 * * \\
(0.013)\end{array}$ & $\begin{array}{l}0.0035 \\
(0.011)\end{array}$ & $\begin{array}{l}0.0019 \\
(0.010)\end{array}$ & \\
\hline Firm size: Large & & $\begin{array}{l}0.0620 \text { *** } \\
(0.022)\end{array}$ & $\begin{array}{l}0.0243 \\
(0.016)\end{array}$ & $\begin{array}{l}0.0209 \\
(0.016)\end{array}$ & \\
\hline Size & & & & & $\begin{array}{l}-0.0357 * \\
(0.020)\end{array}$ \\
\hline Size (squared) & & & & & $\begin{array}{l}0.0092 * * \\
(0.005)\end{array}$ \\
\hline Labour costs & & $\begin{array}{l}-0.0141 \\
(0.012)\end{array}$ & & $\begin{array}{l}-0.0067 \\
(0.010)\end{array}$ & $\begin{array}{l}-0.0075 \\
(0.010)\end{array}$ \\
\hline Demand & & $\begin{array}{l}-0.0084 \\
(0.012)\end{array}$ & & $\begin{array}{l}-0.0236 * * \\
(0.010)\end{array}$ & $\begin{array}{l}-0.0246^{* * *} \\
(0.009)\end{array}$ \\
\hline Material input costs & & $\begin{array}{l}-0.0197 \\
(0.021)\end{array}$ & & $\begin{array}{l}-0.0040 \\
(0.019)\end{array}$ & $\begin{array}{l}-0.0067 \\
(0.020)\end{array}$ \\
\hline Chain & & $\begin{array}{l}0.0054 \\
(0.012)\end{array}$ & $\begin{array}{l}0.0167^{*} \\
(0.010)\end{array}$ & $\begin{array}{l}0.0159 * \\
(0.009)\end{array}$ & $\begin{array}{l}0.0149 * \\
(0.009)\end{array}$ \\
\hline Storage & & $\begin{array}{l}-0.0347 * * \\
(0.015)\end{array}$ & $\begin{array}{l}-0.0366^{* * * *} \\
(0.013)\end{array}$ & $\begin{array}{l}-0.0330 * * \\
(0.013)\end{array}$ & $\begin{array}{l}-0.0300 * * \\
(0.012)\end{array}$ \\
\hline Mall location & & $\begin{array}{l}0.0160 \\
(0.016)\end{array}$ & $\begin{array}{l}0.0115 \\
(0.015)\end{array}$ & $\begin{array}{l}0.0066 \\
(0.014)\end{array}$ & $\begin{array}{l}0.0045 \\
(0.015)\end{array}$ \\
\hline Urban & & $\begin{array}{l}-0.0288^{* *} \\
(0.012)\end{array}$ & $\begin{array}{l}0.0013 \\
(0.010)\end{array}$ & $\begin{array}{l}0.0006 \\
(0.010)\end{array}$ & $\begin{array}{l}0.0030 \\
(0.010)\end{array}$ \\
\hline Constant & $\begin{array}{l}0.2769 * * * \\
(0.010)\end{array}$ & $\begin{array}{l}0.3271 \text { *** } \\
(0.026)\end{array}$ & $\begin{array}{l}0.3242 * * * \\
(0.014)\end{array}$ & $\begin{array}{l}0.3490 * * * \\
(0.023)\end{array}$ & $\begin{array}{l}0.3826 * * * \\
(0.031)\end{array}$ \\
\hline Observations & 7012 & 7012 & 7012 & 7012 & 7012 \\
\hline Clusters & 210 & 210 & 210 & 210 & 210 \\
\hline \multicolumn{6}{|l|}{ Fixed effects } \\
\hline Product & $\mathrm{N}$ & $\mathrm{N}$ & $\mathrm{Y}$ & $\mathrm{Y}$ & $\mathrm{Y}$ \\
\hline District & $\mathrm{N}$ & $\mathrm{N}$ & $\mathrm{Y}$ & $\mathrm{Y}$ & $\mathrm{Y}$ \\
\hline
\end{tabular}

1) Regressions use the integrated survey and BOS historical price data. 2) The monthly average frequency of price changes are for the period January 2011 to December 2012 and independent variables are from the survey conducted in 2013. 3) Small outlets (5 employees or less) are the omitted category in the outlet size variable. Medium outlets employ 6 to 20 employees, while large outlets employ above 20. 4) Robust standard errors clustered at the outlet level in parentheses. 5) *** $p<0.01, * * p<0.05, * p<0.1$

Overall, we find evidence of a non-monotonic relationship, which is consistent with a model of increasing costs of coordinating price changes under tacit collusion with few competitors and a breakdown of collusion at higher levels of competition. Our argument is that as the number of outlets increases initially, coordination costs associated with price changes outweigh any gains from adjusting prices to demand shocks, until collusion is ultimately unsustainable and prices adjust to shocks. Our result thus emphasizes the fact that the relationship between price rigidity and competition may be quite nuanced, especially in markets characterized by strong information asymmetries or barriers to information flows. We ensure that our results are qualitatively consistent with replacing the squared term of the competition variable with categorical variables for the competitors to pick up the u-shape. The reference category is firms with more than 20 competitors. The results presented in Table 7 reveal the u-shaped relationship in all the estimates subject to various controls. 


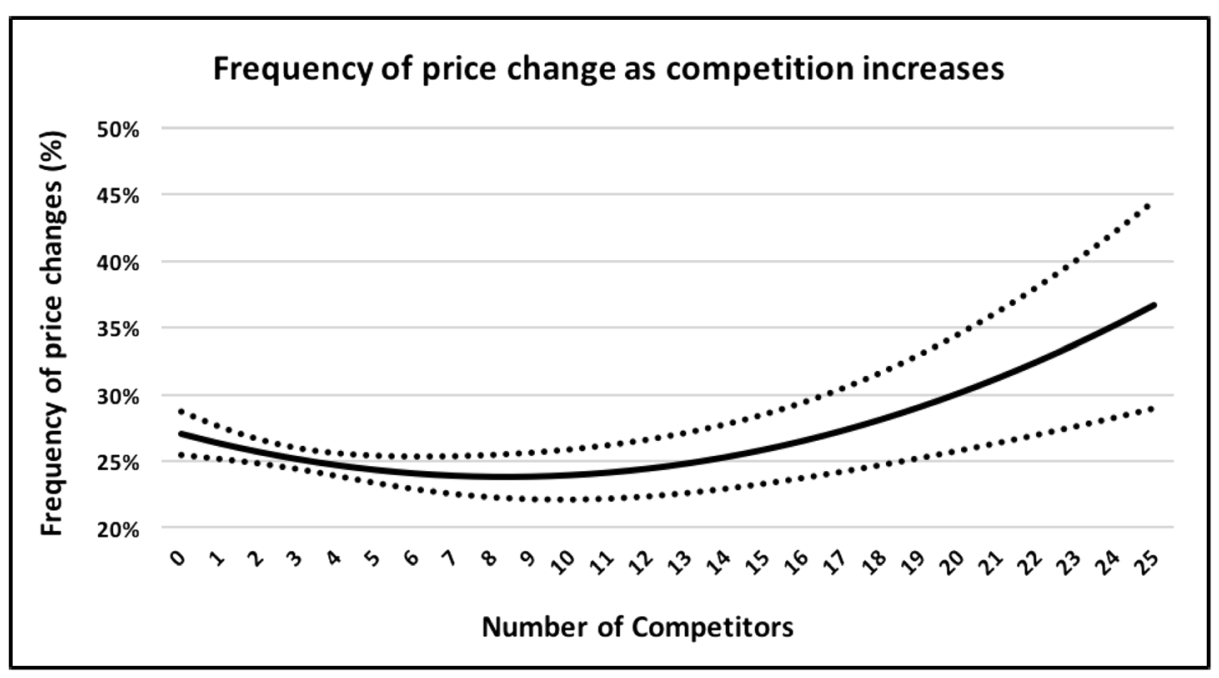

Fig. 1 Frequency of price change and number of competitors Notes: The figure plots the distribution of the fitted regression in Eq. 3 presented as estimates in column 4 of Table 6 . The dotted lines represent the $95 \%$ confidence interval bands computed at each level of number of competitors

\subsection{The Frequency of Price Increases and Price Decreases}

Next, we explore the non-monotonic relationship between perceived competition and the frequency of price increases and decreases. While theory suggests symmetrical effects in price changes, empirical evidence shows that price increases and decreases respond asymmetrically to cost and demand shocks (Peltzman 2000; Blinder et al. 1998; Klenow and Kryvtsov 2008; Klenow and Malin 2011 and; Nchake et al. 2015). We test if asymmetric effects are also present in the relationship between price rigidity and competition.

Results presented in Table 8 show evidence of the relationship between competition and the frequency of price increases and price decreases. As shown by the coefficient on the constant term, the frequency of price increases far exceeds that of price decreases over the period of analysis. However, we find no statistically significant difference in the relationship between competition and price changes for price increases and decreases. In both cases we find evidence of a non-monotonic relationship. At low levels of competition, at one competitor for instance, the frequency of price decreases is $9 \%$ and of price increases, $25 \%$. A rise in the number of competing outlets to 10 reduces the frequency of price decreases to $8 \%$ and the frequency of price increases to $24 \%$. At a higher level of competition (20 competitors), the frequencies of price decreases and price increases rise to 11 and $31 \%$ respectively.

\subsection{Robustness Checks}

The conceptual framework we posit in this paper is most relevant for homogenous products. This is because the more differentiated the product, the more likely a shock experienced by a retail outlet will be product-specific and specific to the outlet, inducing outlets to respond by changing prices. The advantage of our data is that we have sufficient information on products to enable us to clearly distinguish between homogeneous and differentiated products. This allows us to ascertain if our results pertain primarily to homogenous products. To evaluate this, we use a sub-sample of 87 
Table 7 Frequency of price changes and perceived competition - measuring competition as a categorical variable

\begin{tabular}{|c|c|c|c|}
\hline Variables & (1) & (2) & (3) \\
\hline No competitors & $\begin{array}{l}-0.0775 * * * \\
(0.028)\end{array}$ & $\begin{array}{l}-0.0819 * * * \\
(0.029)\end{array}$ & $\begin{array}{l}-0.0661 * * * \\
(0.024)\end{array}$ \\
\hline Between 1 and 5 competitors & $\begin{array}{l}-0.0834 * * * \\
(0.025)\end{array}$ & $\begin{array}{l}-0.0845 * * * \\
(0.026)\end{array}$ & $\begin{array}{l}-0.0677 * * * \\
(0.022)\end{array}$ \\
\hline Between 6 and 10 competitors & $\begin{array}{l}-0.1040 * * * \\
(0.024)\end{array}$ & $\begin{array}{l}-0.1049 * * * \\
(0.024)\end{array}$ & $\begin{array}{l}-0.0855^{* * * *} \\
(0.021)\end{array}$ \\
\hline Between 11 and 15 competitors & $\begin{array}{l}-0.0885 * * * \\
(0.030)\end{array}$ & $\begin{array}{l}-0.0847 * * * \\
(0.030)\end{array}$ & $\begin{array}{l}-0.0694 * * \\
(0.028)\end{array}$ \\
\hline Between 16 and 20 competitors & $\begin{array}{l}-0.1176^{* * * *} \\
(0.030)\end{array}$ & $\begin{array}{l}-0.1161 * * * \\
(0.031)\end{array}$ & $\begin{array}{l}-0.0965 * * * \\
(0.028)\end{array}$ \\
\hline Firm size: Medium & $\begin{array}{l}0.0008 \\
(0.010)\end{array}$ & & \\
\hline Firm size: Large & $\begin{array}{l}0.0200 \\
(0.017)\end{array}$ & & \\
\hline Size & & $\begin{array}{l}-0.0390 * * \\
(0.019)\end{array}$ & $\begin{array}{l}-0.0364 * \\
(0.019)\end{array}$ \\
\hline Size (squared) & & $\begin{array}{l}0.0097 * * * \\
(0.004)\end{array}$ & $\begin{array}{l}0.0092 * * \\
(0.005)\end{array}$ \\
\hline Labour costs & $\begin{array}{l}-0.0075 \\
(0.010)\end{array}$ & $\begin{array}{l}-0.0082 \\
(0.010)\end{array}$ & \\
\hline Demand & $\begin{array}{l}-0.0223^{* *} \\
(0.010)\end{array}$ & $\begin{array}{l}-0.0234 * * \\
(0.009)\end{array}$ & \\
\hline Material input costs & $\begin{array}{l}-0.0029 \\
(0.020)\end{array}$ & $\begin{array}{l}-0.0056 \\
(0.019)\end{array}$ & \\
\hline Chain & $\begin{array}{l}0.0155^{*} \\
(0.009)\end{array}$ & $\begin{array}{l}0.0141 \\
(0.009)\end{array}$ & $\begin{array}{l}0.0150 \\
(0.009)\end{array}$ \\
\hline Storage & $\begin{array}{l}-0.0285 * * \\
(0.013)\end{array}$ & $\begin{array}{l}-0.0249 * * \\
(0.012)\end{array}$ & $\begin{array}{l}-0.0293 * * \\
(0.011)\end{array}$ \\
\hline Mall location & $\begin{array}{l}0.0062 \\
(0.014)\end{array}$ & $\begin{array}{l}0.0042 \\
(0.015)\end{array}$ & $\begin{array}{l}0.0098 \\
(0.017)\end{array}$ \\
\hline Urban & $\begin{array}{l}0.0000 \\
(0.010)\end{array}$ & $\begin{array}{l}0.0029 \\
(0.011)\end{array}$ & $\begin{array}{l}0.0043 \\
(0.010)\end{array}$ \\
\hline Constant & $\begin{array}{l}0.4100 * * * \\
(0.037)\end{array}$ & $\begin{array}{l}0.4490 * * * \\
(0.043)\end{array}$ & $\begin{array}{l}0.4064 * * * \\
(0.030)\end{array}$ \\
\hline Observations & 7012 & 7012 & 7012 \\
\hline Clusters & 210 & 210 & 210 \\
\hline Fixed effects & & & \\
\hline Product & $\mathrm{Y}$ & $\mathrm{Y}$ & $\mathrm{Y}$ \\
\hline District & $\mathrm{Y}$ & $\mathrm{Y}$ & $\mathrm{Y}$ \\
\hline
\end{tabular}

1) Regressions use the integrated survey and BOS historical price data. 2) The monthly average frequency of price changes are for the period January 2011 to December 2012 and independent variables are from the survey conducted in 2013. 3) Small outlets (5 employees or less) are the omitted category in the outlet size variable. Medium outlets employ 6 to 20 employees, while large outlets employ above 20. 4) Reference category is firms with more than 20 competitors. 5) Robust standard errors clustered at the outlet level in parentheses. 6) $* * *$ $p<0.01, * * p<0.05, * p<0.1$

homogeneous products that are similar in their product description and unit of measurement. These include, for example, $750 \mathrm{ml}$ of cooking oil, $500 \mathrm{~g}$ of rice, $500 \mathrm{ml}$ of bottled water, $1 \mathrm{~kg}$ of beef or $1 \mathrm{~kg}$ of apples. We compare this sample to a sub-sample of 49 differentiated products.

In column 1 of Table 9, we present results for Eq. (3) for homogenous products and in column 2, for differentiated products. We present results for perishable food products $(35$ products), non-perishable food products (45 products) and non-food products in columns 3, 4 
Table 8 Frequency of price increases and decreases

\begin{tabular}{|c|c|c|}
\hline Variables & $\begin{array}{l}\text { (1) } \\
\text { Frequency plus }\end{array}$ & $\begin{array}{l}(2) \\
\text { Frequency minus }\end{array}$ \\
\hline Number of competitors & $\begin{array}{l}-0.0037^{*} \\
(0.002)\end{array}$ & $\begin{array}{l}-0.0038 * * * \\
(0.001)\end{array}$ \\
\hline Sqr of number of competitors & $\begin{array}{l}0.0003 * * * \\
(0.000)\end{array}$ & $\begin{array}{l}0.0002^{* * * *} \\
(0.000)\end{array}$ \\
\hline Firm size: Medium & $\begin{array}{l}0.0011 \\
(0.009)\end{array}$ & $\begin{array}{l}0.0014 \\
(0.004)\end{array}$ \\
\hline Firm size: Large & $\begin{array}{l}0.0119 \\
(0.013)\end{array}$ & $\begin{array}{l}0.0120 * * \\
(0.006)\end{array}$ \\
\hline Labour costs & $\begin{array}{l}-0.0076 \\
(0.007)\end{array}$ & $\begin{array}{l}-0.0030 \\
(0.004)\end{array}$ \\
\hline Demand & $\begin{array}{l}-0.0026 \\
(0.010)\end{array}$ & $\begin{array}{l}-0.0062 * \\
(0.004)\end{array}$ \\
\hline Material input costs & $\begin{array}{l}-0.0091 \\
(0.013)\end{array}$ & $\begin{array}{l}0.0039 \\
(0.004)\end{array}$ \\
\hline Chain & $\begin{array}{l}0.0123 * \\
(0.007)\end{array}$ & $\begin{array}{l}0.0050 \\
(0.004)\end{array}$ \\
\hline Storage & $\begin{array}{l}-0.0298 * * * \\
(0.010)\end{array}$ & $\begin{array}{l}-0.0039 \\
(0.004)\end{array}$ \\
\hline Mall location & $\begin{array}{l}0.0009 \\
(0.011)\end{array}$ & $\begin{array}{l}0.0094 * \\
(0.005)\end{array}$ \\
\hline Urban & $\begin{array}{l}-0.0032 \\
(0.008)\end{array}$ & $\begin{array}{l}0.0037 \\
(0.004)\end{array}$ \\
\hline Constant & $\begin{array}{l}0.2496 \text { *** } \\
(0.017)\end{array}$ & $\begin{array}{l}0.0886 \text { *** } \\
(0.006)\end{array}$ \\
\hline Observations & 7012 & 7012 \\
\hline Clusters & 210 & 210 \\
\hline Fixed effects & & \\
\hline Product & $\begin{array}{l}\mathrm{Y} \\
\mathrm{Y}\end{array}$ & $\begin{array}{l}\mathrm{Y} \\
\mathrm{Y}\end{array}$ \\
\hline
\end{tabular}

1) Regressions use the integrated survey and BOS historical price data. 2) The monthly average frequency of price changes are for the period January 2011 to December 2012 and independent variables are from the survey conducted in 2013. 3) Small outlets (5 employees or less) are the omitted category in the outlet size variable. Medium outlets employ 6 to 20 employees, while large outlets employ above 20. 4) Labor costs, material input costs and Demand are dummies that equal one if the outlet reports these as important or very important in driving price increases in column (1) and price decreases in column (2). 5) Robust standard errors clustered at the outlet level in parentheses. 6) *** $p<0.01, * * p<0.05, * p<0.1$

and 5 respectively. The idea behind this split is to ask if the non-monotonic relationship between competition and the frequency of price changes differs for products with relatively flexible prices versus for products with relatively sticky prices.

Consistent with our conceptual framework, we find that the non-monotonic relationship between the frequency of price changes and competition is statistically significant for homogeneous products and not for differentiated products. We find that the non-monotonic relationship between the frequency of price changes and competition is stronger for perishable food products than for non-perishable food products, though the relationship is statistically significant in both cases. Estimated coefficients are not significant for non-food products.

We conduct additional robustness checks in Table 10. The results so far are estimated using OLS. To deal with functional form and concerns of inference when using bounded data on the dependent variable, such as the frequency of price changes, we test the robustness of our 
Table 9 Robustness check: homogenous and differentiated products

\begin{tabular}{|c|c|c|c|c|c|}
\hline Variables & $\begin{array}{l}\text { (1) } \\
\text { Homogenous } \\
\text { products }\end{array}$ & $\begin{array}{l}\text { Differentiated } \\
\text { products }\end{array}$ & $\begin{array}{l}(3) \\
\text { Perishable food } \\
\text { products }\end{array}$ & $\begin{array}{l}\text { Non-perishable } \\
\text { products }\end{array}$ & $\begin{array}{l}(5) \\
\text { Non-food } \\
\text { products }\end{array}$ \\
\hline Number of & $-0.0103 * * *$ & -0.0002 & $-0.0131 * *$ & $-0.0046^{*}$ & -0.0047 \\
\hline competitors & $(0.003)$ & $(0.003)$ & $(0.007)$ & $(0.004)$ & $(0.006)$ \\
\hline $\begin{array}{l}\text { Sqr of number } \\
\text { of }\end{array}$ & $0.0006 * * *$ & -0.0001 & $0.0010 * * *$ & $0.0004 * *$ & 0.0001 \\
\hline competitors & $(0.000)$ & $(0.000)$ & $(0.000)$ & $(0.000)$ & $(0.000)$ \\
\hline Firm size: & 0.0001 & 0.0083 & $0.0477 * *$ & -0.0157 & $0.0412 * *$ \\
\hline Medium & $(0.011)$ & $(0.013)$ & $(0.023)$ & $(0.010)$ & $(0.020)$ \\
\hline Firm size: & 0.0078 & $0.0556^{* * *}$ & $0.0800 * *$ & -0.0105 & $0.0827 * * *$ \\
\hline Large & $(0.018)$ & $(0.020)$ & $(0.039)$ & $(0.017)$ & $(0.030)$ \\
\hline \multirow[t]{2}{*}{ Labour costs } & -0.0051 & -0.0097 & -0.0064 & -0.0096 & -0.0153 \\
\hline & $(0.012)$ & $(0.011)$ & $(0.022)$ & $(0.010)$ & $(0.016)$ \\
\hline \multirow[t]{2}{*}{ Demand } & $-0.0279 * *$ & -0.0152 & $-0.0468^{* *}$ & -0.0160 & -0.0066 \\
\hline & $(0.011)$ & $(0.012)$ & $(0.022)$ & $(0.010)$ & $(0.018)$ \\
\hline \multirow{2}{*}{$\begin{array}{l}\text { Material input } \\
\text { costs }\end{array}$} & -0.0140 & $0.0347 * *$ & -0.0047 & -0.0182 & -0.0308 \\
\hline & $(0.021)$ & $(0.016)$ & $(0.025)$ & $(0.023)$ & $(0.026)$ \\
\hline \multirow[t]{2}{*}{ Chain } & $0.0213 * *$ & -0.0082 & 0.0152 & 0.0119 & -0.0134 \\
\hline & $(0.011)$ & $(0.011)$ & $(0.017)$ & $(0.011)$ & $(0.013)$ \\
\hline \multirow[t]{2}{*}{ Storage } & $-0.0400 * *$ & -0.0120 & $-0.0590 * *$ & -0.0176 & -0.0074 \\
\hline & $(0.015)$ & $(0.012)$ & $(0.026)$ & $(0.011)$ & $(0.024)$ \\
\hline \multirow[t]{2}{*}{ Mall location } & 0.0115 & -0.0047 & -0.0317 & 0.0130 & 0.0309 \\
\hline & $(0.016)$ & $(0.015)$ & $(0.034)$ & $(0.015)$ & $(0.022)$ \\
\hline \multirow[t]{2}{*}{ Urban } & -0.0069 & $0.0317 * *$ & $-0.0607 * *$ & 0.0067 & 0.0095 \\
\hline & $(0.011)$ & $(0.014)$ & $(0.024)$ & $(0.010)$ & $(0.021)$ \\
\hline \multirow[t]{2}{*}{ Constant } & $0.3756 * * *$ & $0.1273 * * *$ & $0.4728 * * *$ & $0.2952 * * *$ & $0.2786^{* * * *}$ \\
\hline & $(0.026)$ & $(0.023)$ & $(0.040)$ & $(0.027)$ & $(0.042)$ \\
\hline Observations & 5746 & 1266 & 1924 & 4178 & 910 \\
\hline Clusters & 181 & 165 & 134 & 129 & 114 \\
\hline \multicolumn{6}{|l|}{ Fixed effects } \\
\hline $\begin{array}{r}\text { Product } \\
\text { group }\end{array}$ & $\mathrm{Y}$ & $\mathrm{Y}$ & $\mathrm{Y}$ & $\mathrm{Y}$ & $\mathrm{Y}$ \\
\hline District & $\mathrm{Y}$ & $\mathrm{Y}$ & $\mathrm{Y}$ & $\mathrm{Y}$ & $\mathrm{Y}$ \\
\hline
\end{tabular}

1) Regressions use the integrated survey and BOS historical price data. 2) The monthly average frequency of price changes are for the period January 2011 to December 2012 and independent variables are from the survey conducted in 2013. 3) Small outlets (5 employees or less) are the omitted category in the outlet size variable. Medium outlets employ 6 to 20 employees, while large outlets employ above 20. 4) Labor costs, material input costs and Demand are dummy variables that equal one if the outlet reports these as important or very important in driving price changes in columns (1) and (2), price increases in columns (3) and (4) and price decreases in columns (5) and (6). 5) Robust standard errors clustered at the outlet level in parentheses. 6) $* * * p<0.01$, ** $p<0.05, * p<0.1$

results to the quasi-maximum likelihood (QML) approach of Papke and Wooldridge (1996) to estimate models with fractional dependent variables. This method has been widely used to account for possible bias when the dependent variable is fractional. The dependent variable is expressed as a bounded nonlinear function of the explanatory variables using a cumulative distribution function. The coefficients are then estimated using a Bernoulli quasi-maximum likelihood estimator. Results for estimation Eq. (3) using the QML approach are presented in column 1 . We find that our results are robust to this alternate estimation technique, with the non-monotonicity reflected. 
Table 10 Robustness checks: an alternate estimation technique

\begin{tabular}{|c|c|c|}
\hline Variables & $\begin{array}{l}\text { (1) } \\
\text { QMLE }\end{array}$ & $\begin{array}{l}(2) \\
\text { Product FE }\end{array}$ \\
\hline Number of competitors & $\begin{array}{l}-0.045 * * * \\
(0.015)\end{array}$ & $\begin{array}{c}-0.023 \\
(0.016)\end{array}$ \\
\hline Square of number of competitors & $\begin{array}{l}0.003 * * * \\
(0.001)\end{array}$ & $\begin{array}{l}0.002 * * \\
(0.001)\end{array}$ \\
\hline Firm size: Medium & $\begin{array}{l}0.007 \\
(0.054)\end{array}$ & $\begin{array}{l}-0.033 \\
(0.052)\end{array}$ \\
\hline Firm size: Large & $\begin{array}{l}0.110 \\
(0.085)\end{array}$ & $\begin{array}{l}0.093 \\
(0.098)\end{array}$ \\
\hline Labour costs & $\begin{array}{l}-0.035 \\
(0.054)\end{array}$ & $\begin{array}{l}-0.061 \\
(0.054)\end{array}$ \\
\hline Demand & $\begin{array}{l}-0.122 * * \\
(0.053)\end{array}$ & $\begin{array}{l}-0.124 * * \\
(0.053)\end{array}$ \\
\hline Material input costs & $\begin{array}{l}-0.016 \\
(0.099)\end{array}$ & $\begin{array}{l}0.014 \\
(0.116)\end{array}$ \\
\hline Chain & $\begin{array}{l}0.089 * \\
(0.050)\end{array}$ & $\begin{array}{l}0.050 \\
(0.052)\end{array}$ \\
\hline Storage & $\begin{array}{l}-0.168 * * \\
(0.068)\end{array}$ & $\begin{array}{l}-0.098^{*} \\
(0.055)\end{array}$ \\
\hline Mall location & $\begin{array}{l}0.045 \\
(0.073)\end{array}$ & $\begin{array}{l}0.006 \\
(0.073)\end{array}$ \\
\hline Urban & $\begin{array}{l}-0.003 \\
(0.054)\end{array}$ & $\begin{array}{l}-0.021 \\
(0.054)\end{array}$ \\
\hline Constant & $\begin{array}{l}-0.589 * * * \\
(0.118)\end{array}$ & $\begin{array}{l}-0.890 \text { *** } \\
(0.159)\end{array}$ \\
\hline Observations & 7012 & 7012 \\
\hline Clusters & 210 & 210 \\
\hline \multicolumn{3}{|l|}{ Fixed effects } \\
\hline Product & $\mathrm{N}$ & $\mathrm{Y}$ \\
\hline Product group & $\mathrm{Y}$ & $\mathrm{N}$ \\
\hline District & $\mathrm{Y}$ & $\mathrm{Y}$ \\
\hline
\end{tabular}

1) The regressions use the integrated survey and BOS historical price data. 2) The monthly average frequency of price changes are for the period January 2011 to December 2012 and an independent variable is from the survey conducted in 2013. 3) Small outlets (5 employees or less) are the omitted category in the outlet size variable. Medium outlets employ 6 to 20 employees, while large outlets employ above 20. 4) Robust standard errors clustered at the outlet level in parentheses. 5) *** $p<0.01, * * p<0.05, * p<0.1$

Finally, we test for robustness of our results to the inclusion of disaggregated product fixed effects instead of the more aggregated product group effects. This accounts for product specific shocks to input costs at a more refined level. Results are presented in column 2 and though the negative effect on the competition term is not precisely estimated, results remain qualitatively robust.

\section{Conclusion}

This paper extends the microeconomic evidence on price-setting using micro price data and outlet survey data for Lesotho, a small, low-income, landlocked economy in Southern Africa. The empirical analysis draws on a unique dataset that combines survey data on outlets with detailed historical information on their product prices to analyze the relationship between price-setting behavior and perceived competition. 
Our results provide some important insights into the nature of retail markets. We find that the market structure for consumer goods in Lesotho is characterised by a high degree of imperfect competition. A high proportion of outlets apply mark-ups over costs when setting prices, while very few outlets set prices according to the price of their main competitor. The latter tend to operate in environments perceived to be more competitive, and are more likely to be located in urban areas. We find a non-monotonic relationship between the frequency of price changes and perceived competition, suggesting that the relationship between price rigidity and market-structure is more nuanced than was previously posited.

Our study makes two important contributions. First, to our knowledge, it is the first study to explore the non-monotonic relationship between price rigidity and competition in the nonfinancial sector, providing a potential resolution to the lack of consensus in the literature exploring the relationship between price rigidity and competition. Second, it looks at market structure and price-setting in a developing country, where markets are characterized by asymmetric information and greater barriers to information flows. We believe that by delving into the nature of the relationship between competition and price rigidity, our study has implications for macroeconomic and competition policy, and underscores the scope for interaction between the two.

Acknowledgments We are grateful for financial support provided by Carnegie Foundation and the Exploratory Research Grant (ref. 223) provided by the Private Enterprise Development in Low-Income Countries (PEDL) research initiative of the Centre for Economic Policy Research (CEPR) and the Department for International Development (DFID). We are especially indebted to the Lesotho Bureau of Statistics for their data and their active participation in the survey. Particular thanks go to Pauline Makopela and Ts'eliso Phafoli, Lesotho Bureau of Statistics. All views expressed in this article are those of the authors and do not necessarily represent the views of, and should not be attributed to, the funders or the Lesotho Bureau of Statistics. We thank participants of the SALDRU seminar at the University of Cape Town and the PEDL conference in London for their valuable comments. Excellent research assistance was provided by JP Sebastian. All errors and omissions remain our own.

Open Access This article is distributed under the terms of the Creative Commons Attribution 4.0 International License (http://creativecommons.org/licenses/by/4.0/), which permits unrestricted use, distribution, and reproduction in any medium, provided you give appropriate credit to the original author(s) and the source, provide a link to the Creative Commons license, and indicate if changes were made.

\section{References}

Álvarez LJ, Hernando I (2007a) The price-setting behavior of Spanish firms: evidence from survey data. In: Fabiani S, Loupias C, Martins F, Sabbatini R (eds) Pricing decisions in the Euro Area: how firms set prices and why. Oxford University Press, Oxford

Álvarez LJ, Hernando I (2007b) Competition and price adjustment in the Euro Area. In: Fabiani S, Loupias C, Martins F, Sabbatini R (eds) Pricing decisions in the Euro Area: how firms set prices and why. Oxford University Press, Oxford

Álvarez LJ, Burriel P, Hernando I (2005) Do decreasing hazard functions or price changes make any sense? European central bank working paper, No. 463

Alvarez L, Dhyne E, Hoeberichts M, Kwapil C, Le Bihan H, Lunnemann P, Martins F, Sabbatini R, Stahl H, Vermeulen P, Vilmunen J (2006) Sticky prices in the euro area: a summary of new micro evidence. J Eur Econ Assoc 4(2-3):575-584

Apel M, Friberg R, Hallsten K (2005) Microfoundations of macroeconomic price adjustment: survey evidence from Swedish firms. J Money Credit Bank 37(2):313-338

Aucremanne L, Druant M (2005) Price-setting behavior in belgium: what can be learned from an ad hoc survey. European central bank working paper, No. 448 
Bayoumi T, Laxton D, Pesenti P (2004) Benefits and spillovers of greater competition in Europe: a macroeconomic assessment. NBER working paper, No 10416

Bils M, Klenow PJ (2004) Some evidence on the importance of sticky prices. J Polit Econ 112(5):947-985

Blinder AS (1991) Why are prices sticky: preliminary results from an interview study. Am Econ Rev 81(2):89100

Blinder AS, Canetti E, Lebow DE, Rudd JB (1998) Asking about prices: a new approach to understanding price stickiness. Russell Sage Foundation Publications, New York

Carlton DW (1986) The rigidity of prices. Am Econ Rev 76:637-658

Clarida R, Gali J, Gertler M (1999) The science of monetary policy: a new Keynesian perspective. J Econ Lit 37(4):1661-1707

Copaciu M, Neagu F, Braun-Erdei H (2010) Survey evidence on price-setting patterns of Romanian firms. Manag Decis Econ 31(2-3):235-247

Domberger S (1979) Price adjustment and market structure. Econ J 89:96-108

Fabiani S, Druant M, Hernando I, Kwapil C, Landau B, Loupias C, Martins F, Mathae T, Sabbatini R, Stokman A (2006) What firms' surveys tell us about price-setting behavior in the Euro area. Int J Cent Bank 2(3):3-47

Greenslade JV, Parker M (2012) New insights into price-setting behavior in the United Kingdom. Econ J 122:558

Hall S, Walsh M, Yates A (2000) Are UK companies price sticky? Oxf Econ Pap 52(3):425-446

Hanazono M, Yang H (2007) Collusion, fluctuating demand and price rigidity. Int Econ Rev 48(2):483-515

Hoeberichts M, Stokman A (2006) Pricing behavior of dutch companies: results of a survey. ECP working paper, No. 607

Jackson W III (1997) Market structure and speed of adjustments: evidence of non-monotonicity. Rev Ind Organ 12:37-57

Klenow PJ, Kryvtsov O (2008) State-dependent or time-dependent pricing: does it matter for recent US inflation? Q J Econ 123:863-904

Klenow PJ, Malin BA (2011) Microeconomic evidence on price-setting. In Friedman B, Woodford M (eds) Handbook of monetary economics, 1st edn, vol. 3, chapter 6. Elsevier, North-Holland, pp 231-284

Lago-Gonzalez R, Salas-Fumas V (2005) Market power and bank interest rate adjustments. Bank of Spain working papers, No. 0539

Nchake MA, Edwards L, Rankin N (2015) Price-setting behavior in Lesotho: stylised facts from consumer retail prices. South Afr J Econ 83:199-219

Papke L, Wooldridge J (1996) Econometric methods for fractional response variables with an application to 401(k) plan participation rates. J Appl Econ 11:619-632

Peltzman S (2000) Prices rise faster than they fall. J Polit Econ 108:466-502

Rotemberg J, Saloner G (1987) The relative rigidity of monopoly pricing. Am Econ Rev 77(5):917-926

Şahinőz S, Saraçoğlu B (2008) Price-setting behavior in turkish industries: evidence from survey data. Turkish economic association discussion paper; No. 2008/3

Schmitt-Grohe S, Uribe M (2004) Optimal fiscal and monetary policy under sticky prices. J Econ Theory 114: 198-230

Vladova Z (2012) Survey evidence on price-setting behaviour of firms in Bulgaria. Bulgarian National Bank series, No. 89/2012

Weiss C (1993) Price inertia and market structure: empirical evidence from Austrian manufacturing. Appl Econ 25:1175-1186 